\title{
Four Newly Named Tongues of Eocene Green River Formation, Northern Piceance Creek Basin, Colorado
}

GEOLOG ICALSURVEY BULLETIN $1394-F$

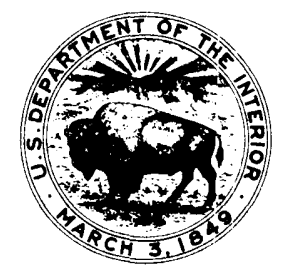




\section{Four Newly Named Tongues of Eocene Green River Formation, Northern Piceance Creek Basin, Colorado}

By D. C. DUNCAN, W. J. HAIL, JR., R. B. O'SULLIVAN, and G. N. PIPIRINGOS

CONTRIBUTIONS TO STRATIGRAPHY

GEOLOGICAL SUR VEY BULLETIN $1394-\mathrm{F}$

Description of new stratigraphic units related to the vast oil-shale deposits of northwestern Colorado

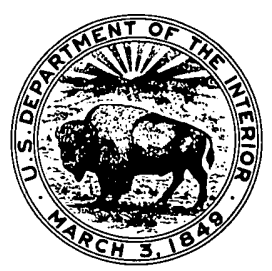




\section{UNITED STATES DEPARTMENT OF THE INTERIOR \\ ROGERS C. B. MORTON, Secretary}

\section{GEOLOGICAL SURVEY}

V. E. McKelvey, Director

Library of Congress catalog-card No. 73-600339

For sale by the Superintendent of Documents, U. S. Government Printing Office Washington, D. C. 20402 - Price 35 cents (paper cover) Stock Number 2401-02457 


\section{CONTENTS}

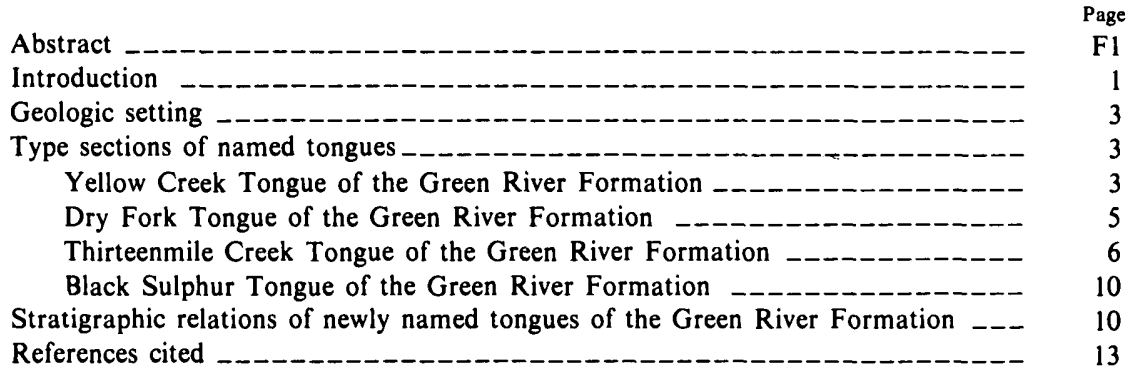

\section{ILLUSTRATIONS}

Figure 1. Index map of northern Piceance Creek basin, Colorado

2. Sections showing stratigraphic relations in the upper part of the Green River Formation and in the lower part of the Uinta Formation in the White River City quadrangle

3. Columnar section and description of the type Thirteenmile Creek Tongue of Green River Formation and related rocks

4. Generalized diagram showing stratigraphic relations of newly named tongues of Green River Formation 


\title{
FOUR NEWLY NAMED TONGUES OF EOCENE GREEN RIVER FORMATION, NORTHERN PICEANCE CREEK BASIN, COLORADO
}

\author{
By D. C. Duncan, W. J. Hail, JR., R. B. O'Sullivan, \\ and G. N. Pipiringos
}

\begin{abstract}
Mapping in the northern part of the Piceance Creek basin, Colorado, shows that several marlstone beds in the Eocene Uinta Formation merge laterally with the Parachute Creek Member of the Eocene Green River Formation. Four of these beds are here formally named and designated as tongues of the Green River Formation. These are, in ascending stratigraphic order, the Yellow Creek, Dry Fork, Thirteenmile Creek, and Black Sulphur Tongues of the Green River Formation.
\end{abstract}

\section{INTRODUCTION}

Recent geologic mapping in the northern part of the Piceance Creek basin (fig.1) shows that several marlstone units of the Green River Formation intertongue with the Uinta Formation of Eocene age. These marlstone units are widespread, and they are readily mappable throughout much of the area. Some of the units were used previously by Kramer (1939) to map the structure of the Piceance Creek anticline. At least 10 marlstone units within the Uinta Formation merge laterally with the Parachute Creek Member of the Green River Formation. We here name four of these marlstone units, designating them as tongues of the Green River Formation. These are, in ascending stratigraphic order, the Yellow Creek, Dry Fork, Thirteenmile Creek, and Black Sulphur Tongues of the Green River Formation.

Mapping these tongues aids in the interpretation of local geologic structures, serves to divide the thick sequence of rocks assigned to the Uinta Formation, and aids in interpretation of the character and thickness of overburden above the oil-shale zones of the Parachute Creek Member.

Formal recognition of other marlstone units may be determined to be appropriate as mapping continues. We have individually mapped other tongues of the Uinta and Green River Formations locally but have not in- 


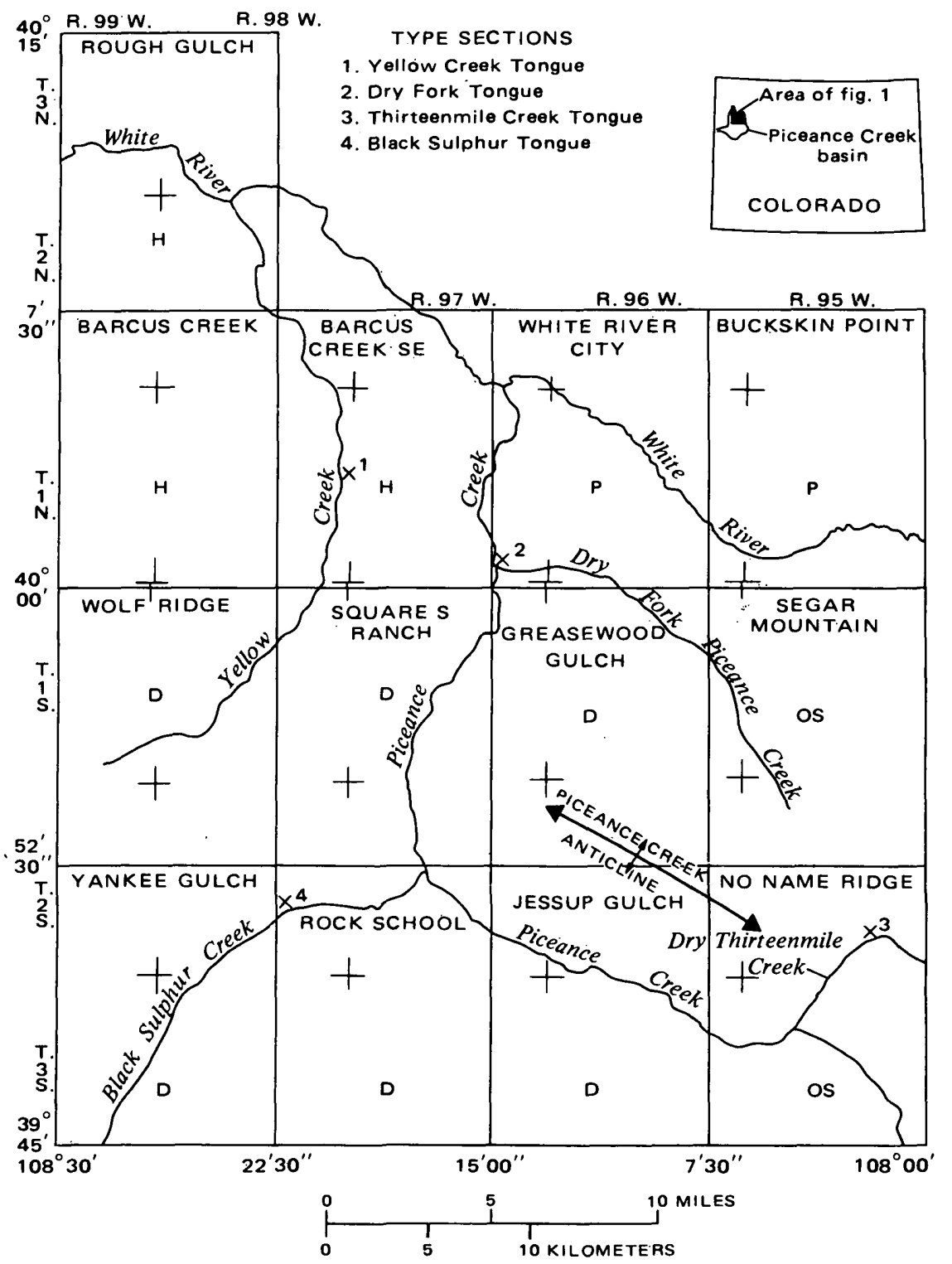

Figure 1. - Index map of northern Piceance Creek basin, Colorado, showing type localities for the four tongues of the Green River Formation, quadrangle names, and the initial of the writer of this report responsible for mapping the quadrangle: D, Duncan; H, Hail; OS, O'Sullivan; and P, Pipiringos.

troduced formal names for them. O'Sullivan (1973) showed the stratigraphic relations of some marlstone tongues of the Green River Formation and the Uinta Formation in the east-central part of Piceance Creek basin. 
Those parts of this report that describe the Yellow Creek, Dry Fork, Thirteenmile Creek, and Black Sulphur Tongues were written by Hail, Pipiringos, O'Sullivan, and Duncan, respectively. However, each author is responsible for statements concerning the stratigraphy of the area he has mapped wherever such statements may appear in the report.

\section{GEOLOGIC SETTING}

All rocks of Eocene age overlying the Eocene Wasatch Formation in the Piceance Creek basin were formerly assigned to the Green River Formation. Recently, however, rocks assigned to the Evacuation Creek Member at the top of the Green River Formation were reassigned to the Uinta Formation, and the name Evacuation Creek Member was abandoned (Cashion and Donnell, 1973). The Parachute Creek Member, which underlies the Uinta Formation, now is the top member of the Green River Formation.

The Parachute Creek Member is at least 1,800 feet thick and consists largely of marlstone. The member contains the richest and thickest oil-shale beds in the Green River Formation. One of these rich oil-shale beds is named the Mahogany ledge at surface outcrops. Because the Mahogany ledge is so widespread, it is useful for correlation. The Mahogany ledge is bounded at the top by a zone of lean oil shale referred to as the "A groove." Another rich oil-shale bed is named the Stillwater zone (Cashion and Donnell, 1972); it lies 140-250 feet above the A groove.

The Uinta Formation, overlying the Green River Formation, is as much as 1,250 feet thick and consists largely of brown sandstone and siltstone with minor beds of mudstone, shale, and light-gray marlstone. It forms much of the surface rock in the Piceance Creek basin.

The Green River Formation was deposited in the Eocene Uinta Lake (Donnell, 1961, p. 862-863), and its rocks reflect the widely varying environments of lacustrine deposition. The Uinta Formation was deposited during the waning stages of the lake; its rocks reflect a change from a lacustrine to a fluvial depositional environment. This change, however, was gradual and fluctuating, resulting in a complex intertonguing relationship between the Green River Formation and the Uinta Formation. Marlstone, a dominant rock type of the Parachute Creek Member of the Green River Formation, was deposited in quiet lake water far from shorelines. Numerous marlstone beds are present in the Uinta Formation. Some of these are lenticular and of limited extent, probably having been deposited in isolated bodies of lake water not connected to Uinta Lake. Other marlstones, however, are of wide lateral extent and continuity and probably were deposited during widespread stages of Uinta Lake.

\section{TYPE SECTIONS OF NAMED TONGUES}

\section{YELLOW CREEK TONGUE OF THE GREEN RIVER FORMATION}

A light-gray to light-brown dominantly marlstone sequence is here named the Yellow Creek Tongue of the Green River Formation, for ex- 
posures along Yellow Creek, in Rio Blanco County, Colo. (fig. 1). It was informally designated as the Yellow Creek marker bed on the preliminary map of the Barcus Creek SE quadrangle (Hail, 1972). The type section of the Yellow Creek Tongue was measured by Hail on the east side of Yellow Creek in the NE1/4SE1/4 sec. 13, T. 1 N., R 98 W., about 150 feet southeast of U.S. Bureau of Mines AEC core hole 1 . The locality may be reached by a graded road that branches off from the Piceance Creek road in sec. 22, T. 1 N., R. 97 W., reaching the valley of Yellow Creek in the NE1/4 sec. 24, T. 1 N., R. $98 \mathrm{~W}$., a distance of about 5 miles; from there, north 0.6 mile along a dirt road on the east side of Yellow Creek to the site of AEC core hole 1.

Type section of Yellow Creek Tongue of Green River Formation

[NE $/ 4 \mathrm{SE}^{1 / 4}$ sec. 13, T. I N., R. 98 W., in the Barcus Creek SE quadrangle, Rio Blanco County, Colo.]

Uinta Formation (part):

Marlstone, olive-green, variably silty, nonresistant

Thickness (fi)

Yellow Creek Tongue of Green River Formation:

Marlstone, light-brownish-gray, variably silty; contains a few thin beds of marly siltstone; gradational from underlying unit; weathers out to thin chips _-_-

Siltstone, very light brownish gray; marly with some thin interbedded marlstone and silty marlstone; weathers out to thin chips; forms upper part of resistant bench

Siltstone, very light gray, calcareous; some wavy bedding and crossbedding; very hard; forms lower part of resistant bench

Marlstone, light-gray to light-brownish-gray, variably silty; contains a few thin beds of marly siltstone; weathers out to thin chips

Siltstone, very light gray; weathers light brown; marly; thin wavy bedding; gradational from underlying unit; forms resistant ledge _..._.

Marlstone, very light brownish gray to light-gray; with a few beds of silty marlstone; upper part is very silty; weathers out in thin chips _._-_._-

Sandstone, light-gray, fine- to medium-grained, calcareous; contains abundant dark grains, including biotite; forms thin resistant ledge _-_.

Siltstone, light-gray, marly; irregular thin bedding -

Marlstone, light- to medium-brown, silty; contains sparse carbonized plant trash; thin bedded; nonresistant; forms mostly covered slope; weathers out in thin chips; sharp contact with underlying unit

Total thickness of Yellow Creek Tongue

Uinta Formation (part):

Sandstone, very light yellow to brownish-gray; weathers very light brown; medium to coarse; contains abundant yellow rusty grains and sparse biotite -..--

The Yellow Creek Tongue crops out in the Barcus Creek, Barcus Creek SE, White River City, and Greasewood Gulch quadrangles. The Yellow Creek Tongue is recognizable in at least the southeastern part of the Rough Gulch quadrangle, but becomes increasingly silty to the west and loses its identity as a distinct marlstone unit. It ranges from 0 to 77 feet in thickness. Variations in thickness are due mostly to changes from marlstone to siltstone in both the upper and lower parts. Locally, however, thinning is due to channeling prior to or during deposition of the overlying sandstone. 
The Yellow Creek Tongue merges with a stratigraphically higher marlstone unit in the extreme southwestern part of the Barcus Creek quadrangle. The combined unit, which locally contains thin oil-shale beds, was mapped separately by Duncan in the Wolf Ridge quadrangle as an unnamed tongue of the Parachute Creek Member of the Green River Formation.

In the White River City quadrangle, the Yellow Creek Tongue thins eastward from about 65 feet thick along the west margin of the quadrangle (fig. 2A) to a feather edge in sec. 27, T. 1 N., R. 96 W. It reappears farther to the southeast near the Juhan 1 Government core hole, where the unit is 77 feet thick, but consists mostly of silty marlstone (fig. 2B). In the southcentral part of the White River City quadrangle (secs. 31, 32, and 33, T. 1 N., R. 96 W.) the tongue is about 10 feet thick and includes a thin bed of oil shale at the top.

\section{DRY FORK TONGUE OF THE GREEN RIVER FORMATION}

The name Dry Fork Tongue of the Green River Formation is here applied to a sequence of light-greenish-gray marlstone, silty marlstone, and calcareous siltstone that is well exposed near the southwest corner of the White River City quadrangle. The type section, designated by Pipiringos, is in the $\mathrm{NE}^{1 / 4} \mathrm{SE}^{1 / 4} \mathrm{NW}^{1 / 4} \mathrm{SE}^{1 / 4}$ sec. $35, \mathrm{~T} .1 \mathrm{~N}$., R. $97 \mathrm{~W}$. It is located about 1,500 feet northeast of the junction of Piceance Creek and the Dry Fork of Piceance Creek on the hillside directly north of the dirt road along Dry Fork. The base of the type section is about 270 feet, and the top is about 340 feet, above the level of the road. At this place the Dry Fork. Tongue is 70 feet thick and contains a light-brown massive sandstone lens, 5-10 feet thick, 10-20 feet above the base.

The lower contact of the Dry Fork Tongue is gradational downward into sandstone whose upper few feet, wherever it is exposed, nearly everywhere contains brown fossil wood in moderate abundance. The upper contact similarly is gradational upward into sandstone, typical of the Uinta Formation, through an interval of about 5-15 feet.

The Dry Fork Tongue is exposed along the south margin of the White River City quadrangle, on the south side of the Dry Fork and in the southeast corner of the quadrangle in adjacent parts of Tps. $1 \mathrm{~N}$. and $1 \mathrm{~S}$., R. $96 \mathrm{~W}$. It ranges in thickness from about 70 feet in the southwestern part to about 30 feet in the southeastern part of the White River City quadrangle. In the northwestern part of the Greasewood Gulch quadrangle, the Dry Fork Tongue is about 60 feet thick. The Dry Fork Tongue is present in the southeastern part of the Barcus Creek SE quadrangle but cannot be identified with certainty to the north and west.

The stratigraphic position of the Dry Fork Tongue is shown in figure 2, which is a composite of subsurface and surface data. Stratigraphic details for column A (fig. 2) from the base of the Yellow Creek Tongue to the top of the Mahogany ledge are based on sample studies, geophysical logs, and U.S. Bureau of Mines assays of cuttings from the Tintic Standard 1-36 
Government well in the NE $1 / 4$ sec. $36, T$. 1 N., $97 \mathrm{~W}$. The well was spudded in alluvium at or just above the top of the Yellow Creek Tongue (ground level $6,100 \mathrm{ft}$ ) and penetrated the top of the Mahogany ledge at a depth of 740 feet. Stratigraphic details from the base of the Yellow Creek Tongue to the top of the Dry Fork Tongue are based on surface measurements made directly west of the well site; details above the Dry Fork Tongue are based on surface measurements south of the well site. Stratigraphic details shown in the lower 200 feet of columnar section B (fig. 2) are from studies of geophysical logs, core studies by J. R. Donnell, and U.S. Bureau of Mines assays of the Juhan 1 Government core hole. This core hole is located on the boundary of the Greasewood Gulch and Segar Mountain quadrangles about 1,000 feet south of the southeast corner of the White River City quadrangle in the $\mathrm{SE}^{1 / 4} \mathrm{NE}^{1 / 4} \mathrm{NE}^{1 / 4} \mathrm{SE}^{1 / 4} \mathrm{sec}$. 2, T. $1 \mathrm{~S}$., R. $96 \mathrm{~W}$. The Juhan hole was spudded in the Stillwater zone (ground level about 6,320 ft) and penetrated the top of the Mahogany ledge at a depth of 178 feet. The upper part of columnar section B is based on a surface section measured from the core hole to an outlier of the Dry Fork Tongue in the SE1/4 SW $1 / 4$ sec. 35, T. 1 N., R. $96 \mathrm{~W}$.

The interval from the Dry Fork Tongue to the Mahogany ledge (base of A groove) increases westward from about 830 feet to about 1,000 feet between the two well sites, owing to an increase in the thickness of sandstone between the base of the Yellow Creek Tongue and the base of the Uinta Formation. The interval between the Dry Fork and Yellow Creek Tongues is relatively constant across the solthern part of the White River City quadrangle, ranging from about 265 feett in the southwest to about 235 feet in the southeast in a distance of about 5 miles.

\section{THIRTEENMILE CREEK TONGUE OF THE GREEN RIVER FORMATION}

A heterogeneous sequence - consisting mostly of marlstone but with appreciable amounts of sandstone, locally ostracodal beds, limestone, and rich but thin oil-shale beds - is here named the Thirteenmile Creek Tongue of the Green River Formation. The name is taken from Dry Thirteenmile Creek, which joins Piceance Creek about 10 miles downstream from the Post Office at Rio Blanco. The type section is readily accessible along a dirt road about 3.5 miles northeast of the paved road along Piceance Creek. A columnar section (fig. 3) rather than a written description is presented to illustrate the type section of the Thirteenmile Creek Tongue and to show its position with respect to adjacent beds.

The stratigraphic section shown in figure 3 is a composite of several measurements made by O'Sullivan at different places along Dry Thirteenmile Creek in T. 2 S., R. 95 W. The units below the Stillwater zone were measured on the south side of Dry Thirteenmile Creek in the SE1/4 sec. 26. The remainder of the various stratigraphic sections was measured on the north side of Dry Thirteenmile Creek in the SW1/4 sec. 26, SE1/4 sec. 27, and NW $1 / 4$ sec. 34. 


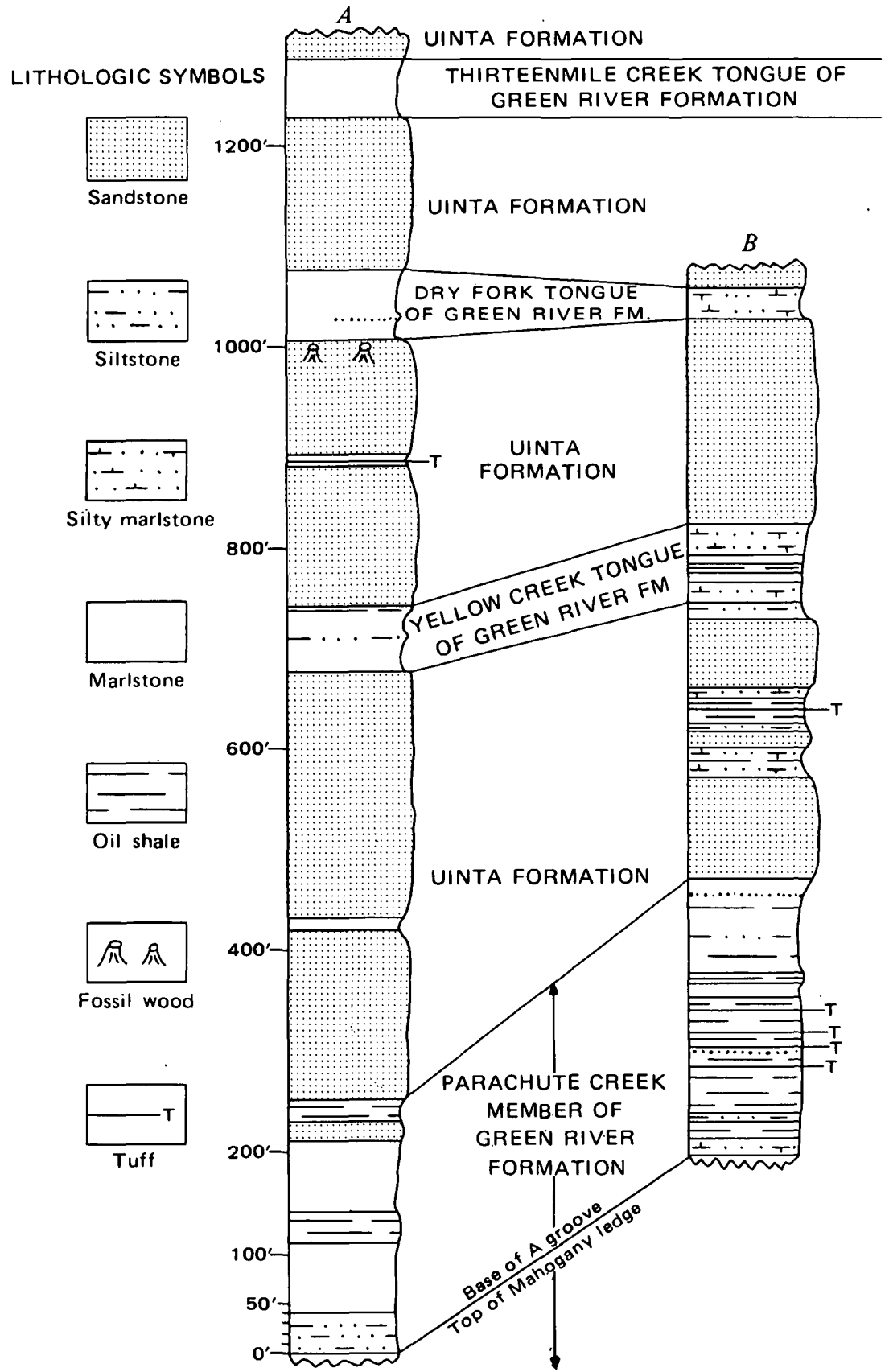

FIGURE 2. - Stratigraphic relations in the upper part of the Green River Formation and in the lower part of the Uinta Formation in the White River City quadrangle. A, The Tintic Standard 1-36 Govt. well, sec. 36, T. 1 N., R. 97 W., and vicinity. B, The Juhan 1 Govt. well, sec. 2, T. 1 S., R. 96 W., and vicinity. 


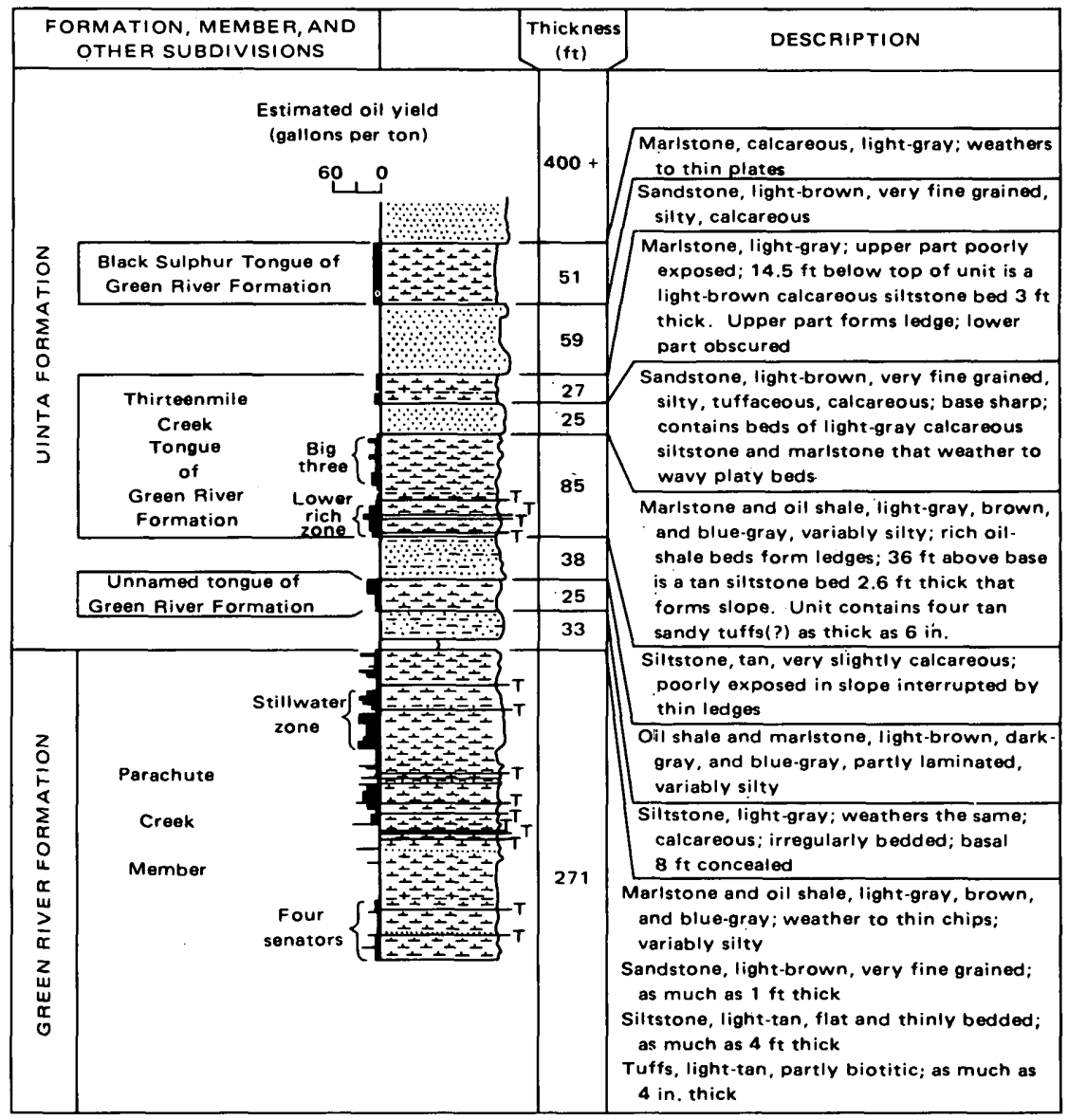

Figure 3. - Columnar section and description of the type Thirteenmile Creek Tongue of the Green River Formation and related rocks at Dry Thirteenmile Creek. Names of rich oilshale beds from Cashion and Donnell (1972). T indicates presumed tuff bed.

The type section of the Thirteenmile Creek Tongue was measured at two localities. The lower 85 feet was measured in the SE1/4NE1/4 SE1/4 sec. 27 on the west side of a reentrant bisected by the common section line of secs. 26 and 27. The lower rich zone at the base of the Thirteenmile Creek Tongue makes a conspicuous finely banded ledge about 100 feet above the floor of the reentrant. The middle sandstone and upper marlstone of the Thirteenmile Creek Tongue were measured on the west side of Open Gulch in the $\mathrm{NW}^{1 / 4} \mathrm{SE}^{1 / 4} \mathrm{SE}^{1 / 4}$ and the NE1/4SW1/4SE1/4 of sec. 27.

At the type section, the Thirteenmile Creek Tongue is 137 feet thick and contains a sandstone bed 25 feet thick near the top. This sandstone bed probably is lenticular and apparently does not join the main body of the Uinta Formation. The bed can be identified in the General Petroleum Corp. 
27-8 test hole drilled in the SW1/4 sec. 8, T. 2 S., R. 95 W., about $41 / 2$ miles northwest of the type section, but where the Thirteenmile Creek Tongue reappears at the surface along Dry Fork of Piceance Creek, the bed is absent.

The outcrop pattern of the Thirteenmile Creek Tongue on the north side of Dry Thirteenmile Creek, near the type section, is complex, and exposures of the tongue on the south side are poor. Consequently, a convenient way to recover the type section of the Thirteenmile Creek Tongue is to locate the Webb Resources, Inc., 22-15 Federal drill hole in the NE $1 / 4 \mathrm{SW}^{1 / 4} \mathrm{SE}^{1 / 4} \mathrm{sec}$. 22, T. 2 S., R. 95 W. The test hole, drilled on the west side of Open Gulch 1 mile north of Dry Thirteenmile Creek was spudded 2 feet below the top of the Thirteenmile Creek Tongue. From the well site, the tongue can be traced easily down to Dry Thirteenmile Creek. A useful stratigraphic marker 130 feet beneath the Thirteenmile Creek Tongue is the conspicuous ledge formed by the Stillwater zone. The position of the Stillwater zone is clearly indicated by the numerous prospect pits in it on the south side of Dry Thirteenmile Creek in sec. 26, T. 2 S., R. 95 W.

The Thirteenmile Creek Tongue, ranging in thickness from 60 to 200 feet, is widespread in the northern part of the Piceance Creek basin. The tongue has been identified in the No Name Ridge, Segar Mountain, Greasewood Gulch, White River City, Jessup Gulch, Rock School, Square S Ranch, Barcus Creek, Barcus Creek SE, and Rough Gulch quadrangles.

The Thirteenmile Creek Tongue has been mapped previously (Hail, 1972) as the Barcus Creek marker bed, an informal unit, in the Barcus Creẹk SE quadrangle. In the Barcus Creek SE, Barcus Creek, and Rough Gulch quadrangles, the Thirteenmile Creek Tongue caps isolated stripped erosion surfaces, and the stratigraphically higher beds are absent.

In the White River City quadrangle, all outcrops but one of the Thirteenmile Creek Tongue are confined to the south side of the Dry Fork of Piceance Creek along the margin of the quadrangle. There, the tongue is about 50 feet thick and caps the higher ridges that project northward from the Greasewood Gulch quadrangle into the White River City quadrangle. The one outcrop of Thirteenmile Creek Tongue not in that area is an outlier of marlstone about 10 feet thick near the $\mathrm{S}^{1 / 2} \mathrm{NW}^{1 / 4} \mathrm{NE}^{1 / 4} \mathrm{sec}$. 3, T. $1 \mathrm{~S}$., R. $95 \mathrm{~W}$., that caps a small isolated hill at about the 6,940-foot contour. The occurrence of a thin ostracodal sandstone ledge in this exposure and the interval down to the Dry Fork Tongue (about $70 \mathrm{ft}$ ) suggests that this is a remnant of the lower unit of the Thirteenmile Creek Tongue, as recognized by Duncan in the Greasewood Gulch quadrangle about 1 mile to the south.

The Thirteenmile Creek Tongue attains a thickness of about 200 feet along Dry Fork of Piceance Creek in the northeastern part of the Greasewood Gulch quadrangle, sec. 10, T. 1 S., R. 96 W., and consists of two parts. The lower part, 75 feet thick, consists of interbedded grayweathering sandstone and marlstone interbedded with a few thin beds of ledge-forming porous algal-ostracodal limestone. The upper part, 50-125 feet thick, consists predominantly of white-weathering marlstone which 
contains a few thin beds of porous algal-ostracodal limestone and locally abundant gastropods.

The lower part lenses out southward in the Greasewood Gulch quadrangle, whereas the upper part is a widespread persistent marlstone to the south. The upper part has been mapped southward to the junction of Black Sulphur Creek and Piceance Creek, in the Rock School quadrangle, and from there northwestward to the northwestern part of the Wolf Ridge quadrangle, where it merges with the main body of the Green River Formation. The composition of the unit changes gradually southward. The algalostracodal limestone beds present in the unit to the north are absent in more southerly outcrops, and in their stead are several thin low-grade oil-shale beds. The Thirteenmile Creek Tongue merges with the main body of the Green River Formation in the subsurface of the central parts of the Rock School and Jessup Gulch quadrangles and in the subsurface and outcrop areas in the western part of the Piceance Creek basin in Yankee Gulch and Wolf Ridge quadrangles. It also merges with the main body of the Green River Formation in the southern part of the No Name Ridge quadrangle in the eastern part of Piceance Creek basin.

\section{BLACK SULPHUR TONGUE OF THE GREEN RIVER FORMATION}

A light-gray marlstone sequence is here named the Black Sulphur Tongue of the Green River Formation, for exposures along Black Sulphur Creek, a tributary to Piceance Creek, in Rio Blanco County, Colo. (fig. 1). The type section is readily accessible and is located about $4 \frac{3}{4}$ miles west of the junction of the dirt road along Black Sulphur Creek and the paved county road along Piceance Creek. The type section, described below, was measured by Duncan in the NW $1 / 4 \mathrm{SW}^{1 / 4} \mathrm{SW}^{1 / 4} \mathrm{sec}$. 23, T. $2 \mathrm{~S}$., R. $98 \mathrm{~W}$. The section starts 600 feet east of the west line of sec. 23 at the base of a spur on the 6,420-foot contour and was measured upslope to the north-northwest.

The Black Sulphur Tongue ranges from about 20 to 60 feet in thickness throughout its outcrop area in most of the central part of the Piceance Creek basin. The tongue is thickest in the northern part of the Jessup Gulch quadrangle and in the southern part of the Greasewood Gulch quadrangle, where a middle sandstone bed as much as 10 feet thick separates upper and lower beds of marlstone. The tongue gradually changes to a gray siltstone in the northern part of the Greasewood Gulch quadrangle, where it becomes indistinguishable from the siltstone of the Uinta Formation. In the southern part of the Rock School quadrangle, the Black Sulphur Tongue also gradually changes to gray siltstone. The tongue merges with the main body of the Green River Formation in the No Name Ridge quadrangle.

\section{STRATIGRAPHIC RELATIONS OF NEWLY NAMED TONGUES OF THE GREEN RIVER FORMATION}

The stratigraphic position of each of the newly named marlstone tongues at or near their type localities is shown in figure 4 . The diagram is 
Type section of the Black Sulphur Tongue of Green River Formation

[NW $1 / 4$ SW $1 / 4$ SW $1 / 4$ sec. 23, T. 2 S., R. 98 W., in the Rock School quadrangle, Rio Blanco County, Colo.]

Uinta Formation (part):

Sandstone, light-gray and tan, friable, tuffaceous; interbedided with siltstone; unit weathers locally to smooth slope, but forms ledges laterally

Black Sulphur Tongue of Green River Formation:

Marlstone, gray and light-brown, silty; weathers to very light gray slope; gradational to overlying unit

Siltstone; weathers tan; calcareous _-

Marlstone, light-gray, silty; forms bench; lower part gradational to siltstone --

Total thickness Black Sulphur Tongue

$\frac{6}{30}$

Uinta Formation (part):

Sandstone, fine-grained, and interbedded siltstone; weathers to tan slopes; base concealed by alluvium

104

generalized, and lithologic detail is omitted. Detailed stratigraphic changes between sections shown on the columns are not precise. It is obvious, however, that there are very large changes in stratigraphic intervals from place to place. Much of this change is due to abrupt changes in the thickness of the dominantly clastic rocks of the Uinta Formation.

The columnar section at Yellow Creek (fig. 4) is a composite of exposed rocks above a horizon near the base of the Yellow Creek Tongue and of subsurface rocks, based on information from studies by Carroll, Coffin, Ege, and Welder (1967, fig.2) and by Trudell, Bear, and Smith (1970, table B-1) of the U.S. Bureau of Mines AEC core hole 1. The stratigraphic interval between the Yellow Creek Tongue and the top of the Mahogany oil-shale zone of the Parachute Creek Member ranges from about 720 feet in the southwestern part of the Barcus Creek SE quadrangle to about 1,220 feet in the east-central part of the Barcus Creek quadrangle.

The columnar section at Dry Fork of Piceance Creek shows the stratigraphic relations near the mouth of the creek in the White River City quadrangle. This column is described in detail under the discussion of the Dry Fork Tongue.

The columnar section at Dry Thirteenmile Creek is a composite of exposed rocks above a horizon about 100 feet above the Mahogany zone and of subsurface rocks, based on information from the Webb Resources, Inc., 22-12 Federal drill hole in the SE1/4 sec. 22, T. 2 S., R. 95 W. The interval from the base of the Thirteenmile Creek Tongue to the top of the Mahogany oil-shale zone of the Parachute Creek Member increases greatly from southeast to northwest. The interval is 450 feet at Dry Thirteenmile Creek, the type section, and is about 1,475 feet in the east-central part of the Barcus Creek quadrangle. The interval is about 380 feet in the central part of the Rock School quadrangle near the line of mergence with the main body of the Green River Formation. 


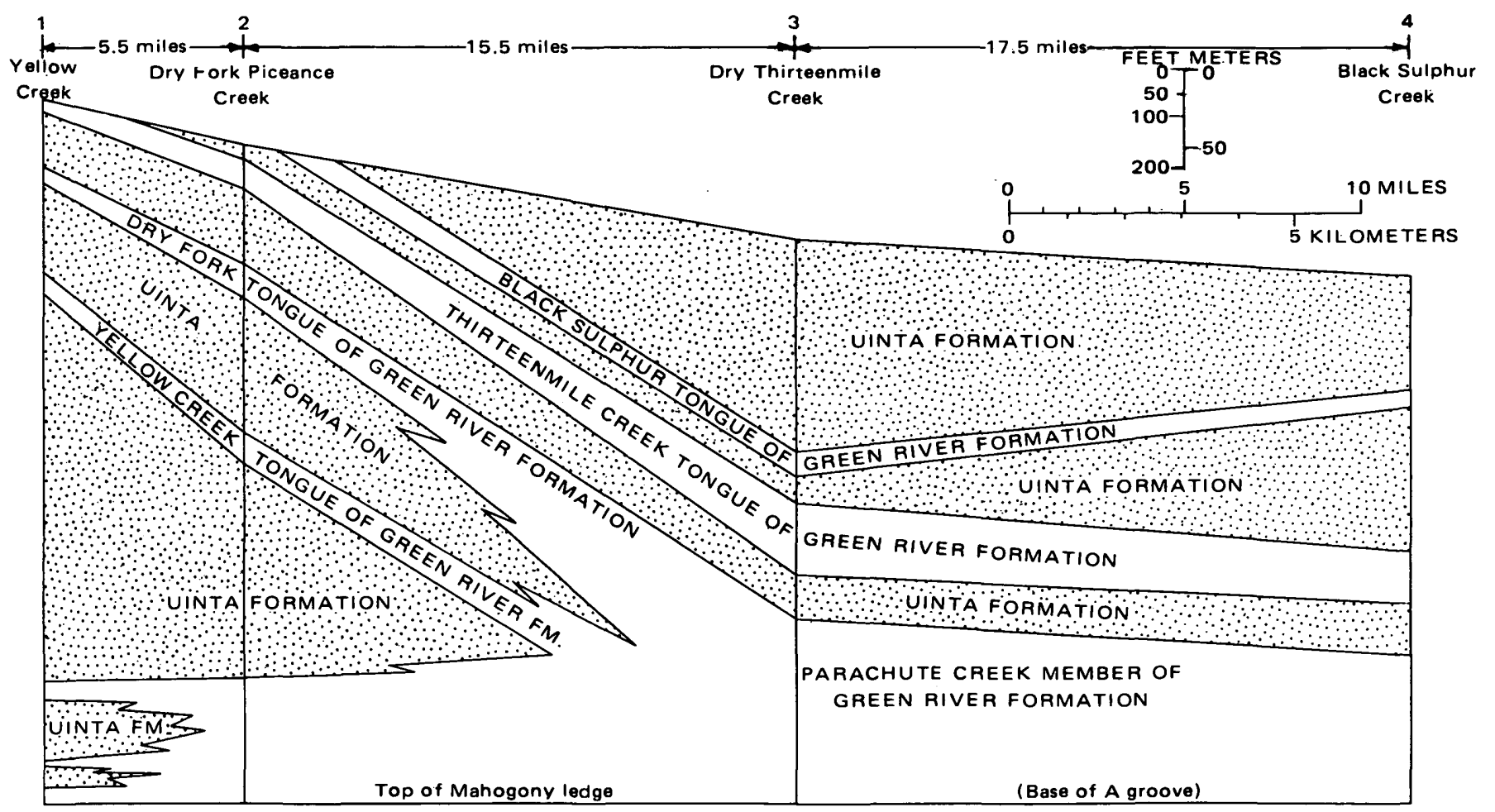

FIGURE 4. - Generalized diagram showing stratigraphic relations of newly named tongues of the Green River Formation. Green River Formation, unpatterned; Uinta Formation, shaded. Datum is top of Mahogany ledge. Vertical exaggeration about $\times 70$. 
The columnar section at Black Sulphur Creek is a composite of exposed rocks above a horizon that is about 100 feet stratigraphically below the base of the Black Sulphur Tongue and of subsurface rocks, based on data derived largely from description of cuttings and the core of Equity Oil Co. Boies 1 core hole in the SW $1 / 4$ sec. 19, T. 2 S., R. $97 \mathrm{~W}$. The stratigraphic interval between the base of the Black Sulphur Tongue and the Mahogany oil-shale zone of the Parachute Creek Member ranges from 570 feet in the southwestern part of the Wolf Ridge quadrangle, to about 1,200 feet in the Segar Mountain quadrangle.

\section{REFERENCES CITED}

Carroll, R. D., Coffin, D. L., Ege, J. R., and Welder, F.A., 1967, Preliminary report on Bureau of Mines Yellow Creek core hole no. 1, Rio Blanco County, Colorado: U.S. Geol. Survey open-file report, TEI-869, $36 \mathrm{p}$.

Cashion, W.B., and Donnell, J. R., 1972, Chart showing correlation of selected key units in the organic-rich sequence of the Green River Formation, Piceance Creek basin, Colorado, and Uinta Basin, Utah: U.S. Geol. Survey Oil and Gas Inv. Chart OC-65.

1973, Revision of nomenclature of the upper part of the Green River Formation, Piceance Creek basin, Colorado, and eastern Uinta Basin, Utah: U.S. Geol. Survey Bull. 1394-G (in press).

Donnell, J. R., 1961, Tertiary geology and oil-shale resources of the Piceance Creek basin between the Colorado and White Rivers, northwestern Colorado: U.S. Geol. Survey Bull. 1082-L, p. 835-891.

Hail, W. J., Jr., 1972, Preliminary geologic map of the Barcus Creek SE quadrangle, Rio Blanco County, Colorado: U.S. Geol. Survey Misc. Field Studies Map MF-347.

Kramer, W. B., 1939; Geologic map and section of Piceance Creek dome, Rio Blanco County, Colorado: U.S. Geol. Survey map.

O'Sullivan, R. B., 1973, Chart showing correlation of selected units of the Eocene Uinta and Green River Formations in east-central Piceance Creek basin, northwestern Colorado: U.S. Geol. Survey Oil and Gas Inv. Chart OC-67 (in press).

Trudell, L. G., Bear, T. N., and Smith, J. W., 1970, Green River Formation lithology and oilshale correlations in the Piceance Creek basin, Colorado: U.S. Bur. Mines Rept. Inv. $7357,14 \mathrm{p}$. 
